\title{
Vaccination in everyday life: experiences indicate Permanent Education
}

\author{
A vacinação no cotidiano: vivências indicam a Educação Permanente \\ La vacunación en el cotidiano: vivencias indican la Educación Permanente
}

Jéssica Rauane Teixeira Martins ${ }^{1}$ (1) Selma Maria da Fonseca Viegas ${ }^{1}$ (1) Valéria Conceição de Oliveira ${ }^{1}$ (D) Heloiza Maria Siqueira Rennó ${ }^{1}$ (D)

1. Universidade Federal de São João del-Rei, Campus Centro Oeste Dona Lindu. Divinópolis, $M G$, Brasil.
Corresponding author:

Selma Maria da Fonseca Viegas.

E-mail: selmaviegas@ufsj.edu.br.

Submitted on $12 / 16 / 2018$.

Accepted on 05/27/2019.

DOI: 10.1590/2177-9465-EAN-2018-0365

\begin{abstract}
Objective: To understand Permanent Education in the daily work in the vaccination room, from the professional's perspective. Method: A holistic-qualitative multiple-case study, based on the Quotidian Comprehensive Sociology, and carried out in four micro-regions of Minas Gerais State, Brazil, with 56 professionals working in seven municipalities. To analyze the data, the Thematic Content Analysis was used associated to the cases' cross-synthesis. Results: The frequent changes in immunization, adverse events, professional accountability, as well as the daily difficulties of working in the vaccination room point to the need for Permanent Education. There is a need for doctors and community health agents to be trained in immunization, just as nurses are previously trained. The importance of Permanent Education for safe work and patient safety in vaccination is evidenced. Conclusion and implications for practice: Considering the relevance and complexity of work in the vaccination room, Permanent Education has the potential to strengthen teamwork, positively impact the care provided to users and provide professionals with more security in the practices carried out.
\end{abstract}

Keywords: Education Continuing; Vaccination; Immunization; Nursing Team; Nurses.

\section{Resumo}

Objetivo: Compreender a Educação Permanente no cotidiano de trabalho em sala de vacinação, sob a ótica do profissional. Método: Estudo de casos múltiplos holístico-qualitativo, fundamentado na Sociologia Compreensiva e do Cotidiano, e realizado em quatro microrregiões de Minas Gerais, Brasil, com 56 profissionais que atuam em sete municípios. Para análise dos dados, utilizou-se a Análise de Conteúdo Temática associada à síntese cruzada dos casos. Resultados: As frequentes alterações em imunização, os eventos adversos, a responsabilização profissional, bem como as dificuldades cotidianas do trabalho em sala de vacinação apontam a precisão de Educação Permanente. Verifica-se a necessidade de médicos e Agentes Comunitários de Saúde serem capacitados em imunização, assim como os profissionais de Enfermagem estarem previamente treinados. Evidenciam-se a importância da Educação Permanente para o trabalho seguro e a segurança do paciente em vacinação. Conclusão e implicações para a prática: Considerando a relevância e a complexidade do trabalho em sala de vacinação, a Educação Permanente tem potencial para fortalecer o trabalho em equipe, impactar positivamente no cuidado prestado aos usuários e proporcionar ao profissional mais segurança nas práticas realizadas.

Palavras-chave: Educação Permanente; Vacinação; Imunização; Equipe de Enfermagem; Enfermeiros.

\section{Resumen}

Objetivo: Comprender la Educación Permanente en el cotidiano de trabajo en sala de vacunación, bajo óptica del profesional. Método: Método de estudio de casos múltiples, cualitativo, fundamentado en la Sociología Comprensiva y del Cotidiano, realizado en cuatro microrregiones de Minas Gerais, Brasil, con 56 profesionales que actúan en siete municipios. análisis de los datos, se utilizó el Análisis de Contenido Temático asociado a la síntesis cruzada de los casos. Resultados: Frecuentes alteraciones en inmunización, los eventos adversos, la responsabilización profesional, así como las dificultades cotidianas del trabajo en sala de vacunación, apuntan a la precisión de Educación Permanente. Existe la necesidad de que los médicos y los Agentes de Salud Comunitarios estén capacitados en inmunización, al igual que las enfermeras han recibido capacitación previamente. Evidencian la importancia de la educación permanente para el trabajo seguro y la seguridad del paciente en vacunación. Conclusión e implicaciones para la práctica: Considerando la relevancia y la complejidad del trabajo en sala de vacunación, la Educación Permanente tiene potencial para fortalecer el trabajo en equipo, impactar positivamente en el cuidado prestado a los usuarios y proporcionar al profesional más seguridad en las prácticas realizadas.

Palabras clave: Educación Continua; Vacunación; Inmunizacíon; Grupo de Enfermería; Enfermeros. 


\section{INTRODUCTION}

This article introduces propositions and/or experiences that allow us to talk about vaccination, addressing the changes that occur in the National Immunization Program (NIP), for the eradication of immunopreventable diseases, the difficulties faced in the daily routine of the vaccination room and the responsibility of nurses and nursing staff in immunization in Brazil. "It comes to sharpen the idea that one must see far enough in the past to be able to see ahead in the future"1:05 to allow us to address the advances in immunization over the last decades, since the creation of the Brazilian NIP in $1973 .^{2}$ It opens a discussion about the daily life in the vaccination room, with a view to the need for Permanent Education (PE) for professionals working in this area. ${ }^{3-6}$

The changes that occur in immunization are presented by the technical notes and national immunization calendars instituted by the NIP incorporating new immunobiological agents, changing vaccine schemes and also the target audience. The first Brazilian vaccination calendar was implemented in the 1970 s, in the $20^{\text {th }}$ century, and presented four immunobiological tests, targeting children from zero to four years..$^{7-8}$

NIP, in 2019, provides 28 vaccines $^{8}$ allocated in specific vaccination calendars for children, adolescents, adults, the elderly, pregnant women and the indigenous population. It also has special immunobiological agents for individuals under special clinical conditions. It also has different vaccination strategies, including routine vaccination, blocking, campaigns and also actions considered extramural. ${ }^{9}$ Therefore, it is an important public health strategy, but complex and filled with challenges to be overcome..$^{10}$

The daily difficulties in the vaccination room are expressed in several realities. Among them, the lack of human resources, lack of immunobiological and equipment, inadequate process of maintenance of the cold chain, including transport and storage of immunobiological agents, and vaccine delay. ${ }^{11}$ There are also difficulties related to the knowledge of professionals working in vaccination rooms.

In the United Kingdom, a study analyzed the doubts of the professionals consulted in an immunobiological counseling center. The main questions of the professionals were about the intervals, administration, contraindication and errors of vaccination, and the doubts consulted increased when there were changes in the immunobiological ones, as when a new vaccine was introduced. ${ }^{12}$

Thus, it is a necessary challenge to introduce PE to professionals who work in the vaccination room, since changes in immunization are frequent. ${ }^{12-15}$ It is also considered the innovation and the technological improvement, as well as the daily situations of the work in health and the particularities that come from the work in team that demand a permanent process of education of the professionals, ${ }^{16}$ including those who work in the vaccination room. A strategy for coping with the problems and difficulties experienced in the daily work in the vaccination room and promoting knowledge is to incorporate PE. ${ }^{14-15,6,17-19}$
In keeping with the concept adopted by the Brazilian Ministry of Health, through the Política Nacional de Educação Permanente em Saúde (Continuing Education in Health Policy), PE can be understood as learning-work and that carries in its theoretical bases pedagogical strategies that use meaningful learning, with a view to achieve the transformation of professional practices. PE comes from the problems faced in the reality, considering the knowledge and the experiences that people already have, as well as the health needs of the populations. ${ }^{20}$

Strengthening PE as a guideline for new practices that guide reflection on work and the construction of collaborative and meaningful learning processes is, therefore, to strengthen the SUS (Sistema Único de Saúde - Brazilian Unified Health System) to offer collective actions with health professionals in permanent training facing the main challenges identified by the teams in everyday work. ${ }^{21}$

As implications for practice, PE is a field that lacks investments in Brazil. It cannot be seen only as a tool to organize the health system or strategy to reshape the work process, with the performance of specific educational courses or actions, restricted to formal moments instituted. It should be understood as a device to mediate changes, allowing the subjects a process of self-analysis at work, in addition to and through work as a possibility of growth to deal with the world. ${ }^{22: 7}$

Even without being seen, this movement of $P E$ is happening as practice and with its effects. This process is constitutive of the world of work itself and occurs without needing to be denominated as a training process, to be, in fact, a place of training. ${ }^{23}$

The responsibility of the professional who works in the vaccination room also indicates the need to incorporate PE into daily work. By demanding safe actions, ensuring the quality of the immunobiological products offered and quality care, PE in the vaccination room must be intrinsic to the work routine. ${ }^{6,24}$

Considering the changes that occur in the NIP, the complexity and difficulties of daily work in the vaccination room, the responsibility of the professionals who work there and the need for ongoing training, are questioned: how does PE occur in the daily work of professionals or are they responsible for the vaccination rooms?

Therefore, this study aims to understand PE in the daily work in the vaccination room, from the professional's perspective.

\section{METHOD}

This is a holistic-qualitative multiple-case study ${ }^{25}$ based on the Quotidian Comprehensive Sociology. ${ }^{26}$ The holistic multiplecase study seeks to comprehend a contemporary phenomenon in a broad, deep and exhaustive way in its real context. ${ }^{25}$ Considering that PE in the vaccination room is indicated in the context of daily practices, it is opportune to use the Quotidian Comprehensive Sociology theoretical framework on the object of study, since it aims to analyze what concerns daily life, the lived experiences, beliefs, and actions of subjects in their environments of relations. ${ }^{26}$ 
The study setting was the Extended Western Region of Minas Gerais State, which has territorial division in six health micro-regions. The multiple cases of this study were defined by the setting, constituting four of these micro-regions determined by the saturation criteria of the data by literal replication. ${ }^{25}$ When saturation was confirmed, data collection was closed.

The number of cases considered necessary or sufficient in multiple-case studies should take into account a discretionary judgment and not follow formulas. Thus, the designation of the number of replications in multiple-case studies depends on the "certainty that is desired to be obtained on the results and meanings that bring the researched reality". ${ }^{25: 64-65}$ In this study, this level was affirmed with data collection in the fourth microregion, conferring $66.67 \%$ of the total of the six micro-regions that compose the Extended Western Region of Minas Gerais, confirmed by data saturation by literal replication. ${ }^{25}$

56 professionals from $26 \mathrm{PHC}$ units from seven municipalities of the four micro-regions participated, including 09 nursing assistants, 17 nursing technicians, 23 nurses and 07 technical references in immunization, and the average duration of immunization was 8.9 years. The number of informants was not previously defined, the closure of the data collection occurred through the literal replication in each case and in the total cases. ${ }^{25}$ The criterion of inclusion was the professional working with vaccination or being a technical reference in immunization of the municipality. The approach of the participants of this study was in person at the health unit where they work. After explaining the purpose of the research and agreeing to participate in the study, formal authorization was requested through the signing of the Free and Informed Consent Term. In order to guarantee the anonymity of the participants of this study, the names of the interviewees were replaced by the letter I, followed by the number of the micro-region belonging $(1,2,3$ or 4$)$ and the sequential number of interviews.

The data collection took place from July 2016 to May 2017. For this collection, the interview was used open and intensive based on a semi-structured script. The interviews were conducted individually, recorded in a digital file and transcribed in full. The script that provided the basis for the interview was composed of eight guiding questions that addressed the participants of the study to $P E$ in the vaccination room and questions to characterize the research participant. In addition, data collection included technical visits to vaccination rooms, operational field notes for the development of the research, and data from technical visits.

The data were analyzed using the Thematic Content Analysis, that is, an analysis of the meanings, according to the pre-analysis, material exploration, treatment of results, inference and interpretation phases. ${ }^{27}$ The analytical technique of the cases' cross-synthesis was obeyed, in agreement with the holisticqualitative multiple-case study methodological framework. ${ }^{25}$ In this way, each case was conducted with a single unit of analysis, the "Permanent Education in the vaccination room", and after the interpretation of the meanings, according to the Analysis
Thematic Content, ${ }^{20}$ the data were crossed, examining the results for each individual case, observing the significant results ${ }^{25}$ for the four cases.

This study was approved in September 2015 under Opinion 1,231,140, CAEE (Certificado de Apresentação para Apreciação Ética - Certificate of Presentation for Ethical Consideration) $47997115,2,0000,5545$, which is part of the Integrated Project called PreveNIr: quality assessment of the National Immunization Program in the Extended Western Region of Minas Gerais, being approved by the Research Program for SUS (PPSUS - Programa de Pesquisa para o SUS), process CBB-APQ-03509-13, which is articulated and deployed in this research.

\section{RESULTS}

Of the 56 nursing professionals participating in the study, nine are nursing assistants, 17 are nursing technicians, 23 are nurses, and 07 are technical references in immunization, of which only two are males. The mean age is 37.6 years, ranging from 22 years to 58 years. The mean time of operation in the vaccination room was 8.9 years, ranging from two weeks to 31 years.

This article addresses the various reasons that point out the necessity of PE in the daily work of the professionals who work in the vaccination room.

\section{Changes in the vaccine calendar and the need for PE}

Because we know that health, the issue of vaccine mainly changes every day. So, for people not to be outdated, not to do wrong, should have PE (I1-2).

Vaccine has many changes so it has to have frequent PE (I1-12).

$P E$ is very important, especially in vaccination, because it is always in constant change, as the shelf-life after open or even the vaccine itself (I3-43).

\section{Adverse events and the demand for PE}

I think any kind of adverse event that happens, or some failure that happens in another unit would be important to be communicating to take precautions and not happen here too (I1-1).

One thing missing is talking about adverse events and expected effect of the vaccine. [...] I think there is this confusion of parents and it is not very clear either. As far as what a local edema, is it expected effect, how far does it become an adverse event? (I1-5).

\section{Difficulties faced in daily life and the need for PE in the vaccination room}

The flow of professionals, the turnover and the precariousness of the hiring process are very detrimental, not only in the vaccination room, in the health unit, but in the link 
with the user. We have in the municipality the reality of a very large turnover of professionals. So we do the training, do a training cycle, finish that training cycle and already have new professionals (11-15).

One problem is that we have doubts about vaccination and often the person responsible for the vaccines cannot clarify them to me (12-19).

Because the basic calendar, it is easy [...] The problem is when a child's card arrives that is all late (I3-41).

\section{Training and education of professionals for immunization}

Because, at the moment, $P E$ is only relied upon when it has insertion of vaccine in the calendar, when it will have some campaign or some change (11-8).

Sometimes, it falls into the routine and we begin to do what is wrong by custom of practicing that way. So PE is good because of that, we review what we do and assess whether we are doing it right or not (14-50).

We feel a bit of difficulty in the matter of people who are hired, sometimes they have never worked in the vaccination room. So, having training before, or if not, when it comes to recruitment and selection is a requirement, to know if the person has had experience $(I 1-7)$.

I believe so, that when the person will start work in FHS, in the vaccination room, had to undergo more rigorous training, you know? [...] Because many people start and do not understand, do not know the right, they have difficulty with techniques (12-28).

\section{Team decision-making of PE needs}

Participants report that they discuss, in a team, the needs that must be addressed in the training and education carried out:

Here we hold team meetings [...] so we always argue with the whole team, before leaving for our training (11-1).

We are always seeing what is lacking in training. [...] We sit down with the nurses on the FHS teams and they talk about what they feel on a day-to-day basis, and report difficulties with the staff, they say, but they do not take it well (I3-36).

\section{Responsibility of the professional involved in vaccination}

I work with vaccine from the knowledge that I have and my responsibility as well. I try to do the most correct thing possible, because I know it's a lot of responsibility, I'm going to manage, is not it? (I1-6)
I work with vaccine from the knowledge that I have and my responsibility as well. I try to do the most correct thing possible, because I know it's a lot of responsibility, I'm going to manage, right? (I3-40).

\section{Lack of(knowledge) of the professional about immunization}

There is a lot of information from the doctor about the vaccine. And we see, mainly, the mothers who have children who go to the pediatrician and arrive here with erroneous information about calendar, about the vaccine itself (I1-5).

I think it takes a longer time to enable CHAs for immunization [...] Because, in fact, the CHA is the flagship of the FHS in whatever action you develop, because it is inserted inside that house, it goes there every month. It is a long time to dedicate to training the CHA to assess the vaccine card, not only to ask if it is up to date and to look superficially, but also to analyze that card and to be actively searching for the child, elderly, teenager (I3-41).

\section{PE for safe operation in vaccination room}

It is very important to have this $P E$, because if you do not get the habit you do not get the safety because it's the first thing to feel safe (11-8).

If you empower, if you learn, seek knowledge, you will take care of the patient more safely. If you train your team too, you do a more appropriate procedure, lessen the discomfort, reactions, especially in the vaccination room (14-49).

I think the state should value this issue of PE more. As it is mandatory to register the grievances in SINAN (Sistema de Informação de Agravos de Notificação - Notification of Injury Information System), I think it should be mandatory for all regional, macro-regions, to have commissions for PE. From the CHA to the doctor, this is essential to be able to make public health well done. Without this, you cannot (14-55).

\section{DISCUSSION}

$P E$ in the vaccination room, in the conceptions of the participants of this study, converges towards the "training" or "updates" that occurred in the face of changes in routine immunization. However, as highlighted in the informants' speeches, the updates available to professionals working in the vaccination room are predominantly developed when there are changes in vaccination calendar, schemes or introduction of new vaccines in the public health network, or in periods of vaccination campaigns. That is, it is not based on the needs and 
problems identified in the daily work in vaccination rooms, going against what is proposed by PNEPS. However, considering the results described and the relevance of the topic and the reflections raised, the discussion links facts of the researched reality to the assumptions of $\mathrm{PE}$ and the evidence found in different national and international realities, bringing contributions to the practice in the vaccination room.

A study conducted in the city of Teresina, Piauí State identified the lack of training of human resources that work with immunobiological agents. The results showed that less than half $(43 \%)$ of vaccination rooms had at least one trained professional less than two years old. ${ }^{28}$

The absence of $\mathrm{PE}$ is a reality that compromises the change in vaccination practices. A study conducted in the Extended Western Region of Minas Gerais also corroborates these findings. The absence of $P E$ is a reality that compromises the change in vaccination practices. A study conducted in the Extended Western Region of Minas Gerais also corroborates these findings. ${ }^{6}$

$\mathrm{PE}$, in line with the one described in the PNEPS, should be guided by problematizing, dialogued and participatory methodologies, in which the professional is actively present in the teaching-learning process, with a view to improving their practices, as well as the continuous improvement. ${ }^{29}$ By actively appearing as a professional in a vaccine ward, "there is not only a production of new knowledge built collectively, but also new training processes, without formally designating this as a place of training or qualification of the employee for the exercise of their functions". ${ }^{23: 09}$

Errors are pointed out as a tool for education about vaccination. Errors in professional practices reveal the importance of implementing strategies to increase patient safety and improve quality of care. Such errors can still be an important learning strategy in order to avoid recurrence. ${ }^{30}$

Vaccines are susceptible to Adverse Events Following Immunization (AEFI), and adequate management of these events requires adequate knowledge of the professionals who deal daily in vaccination rooms. However, knowledge about AEFI is still deficient, with the important SP being allied to alleviating such deficiencies. ${ }^{24}$

In Kenya, a study with nurses identified that $51.8 \%$ of the participants had not undergone training on AEFI. When assessing the knowledge of these professionals about the subject, only $29.2 \%$ presented adequate knowledge. They also identified that nurses who have undergone some training on AEFI are 2.7 times more likely to have better knowledge about the subject and 1.8 times more likely to have better AEFI practices. They also add the need to develop educational strategies on the subject. ${ }^{31}$

The constant changes that occur in immunobiological agents also reveal the need for PE, as highlighted by the participants of this study.

Knowledge about immunobiological agents is constantly being updated, due to the advances that occur in the area and the constant changes that occur in the NIP. In addition to advances in the field of immunization, there are the particularities of each immunobiological and the overload of work that require PE to professionals working in a vaccination room. ${ }^{6,28}$

The beginning of the work in the vaccination room requires a previous knowledge about the immunobiological agents, either by means of knowledge already acquired or by the accomplishment of qualification of the professional, however not always this process of training. Professionals are predominantly entered into vaccination rooms without prior training and learn about day-today vaccinations with other professionals. ${ }^{6}$ For Maffesoli, there is the incorporated knowledge, in which the individual is perfecting himself with what is before him, "this famous 'stock of knowledge' that we use without paying much attention". ${ }^{32: 150} \mathrm{He}$ also adds that in the individual "there is a strange drive, [...] instinct, that compels me to do as the other". ${ }^{32: 150}$

When professionals are actively inserted into the educational process and when learning becomes meaningful to professionals, $P E$ results in a transformation of practices and, consequently, a change in daily work. Thus, "the activity that is intended to become a practice with $P E$ is not a new habit, which simply repeats itself, but rather, another way of thinking or acting". ${ }^{33: 04}$

The responsibility of the professional who works in the vaccination room is also mentioned by the participants of this study as an important aspect that the PE demands, since an immunobiological administered improperly can compromise the health of the individual. The significant amount of inadequate procedures in immunobiological administration (nine procedures per 1,000 doses administered) was identified in a study conducted in the city of Ribeirão Preto, São Paulo State, which demonstrated the need to incorporate PE into the daily work of the professionals who work in the room of vaccine, in order to ensure the improvement of the care provided. ${ }^{34}$

A study conducted in the Republic of Korea has identified an annual average of 278 cases of AEFI. ${ }^{35}$ These data corroborate the responsibility of the professionals who deal daily with the administration of the immunobiological agents, since errors of conservation, handling and application of the immunobiological can result in AEFI.

The need to develop educational strategies on immunization was evidenced not only for the professionals who are dealing directly with the immunobiological, but with the whole PHC team, especially the medical professionals and the $\mathrm{CHA}$. Shortcomings in doctors' knowledge regarding vaccination demonstrate the need to develop educational activities on immunization for these professionals. ${ }^{36}$ However, PE actions are still incipient. In addition, all members of the health team should be able to provide information on vaccination, and the user's contact with any member of the team is a stimulus to vaccination for such professionals. ${ }^{14}$ The professional's knowledge and the way they establish dialogue with the user may interfere with the vaccination. In this way, the professional must be educated through a critical and reflective view that can be provided by the PE. ${ }^{14}$ 
$\mathrm{CHA}$ has a fundamental role in the active search for immunization, to enter the homes, to have knowledge of the reality and to have a bond with the families and community. However, there are still incipient $P E$ vaccination actions for these professionals. A study conducted in Teresina-PI identified that of the $106 \mathrm{CHAs}$ that participated in the research, only $43.4 \%$ received training on vaccination. Concerning the knowledge of these professionals about vaccination, only $18.9 \%$ of the participants had adequate knowledge. ${ }^{37}$ Such information reveals the deficits in both the training and the knowledge of these professionals on the subject of vaccination, as well as the need to implant the vaccination $\mathrm{PE}$ for $\mathrm{CHA}$.

The turnover of health professionals, among them, those who work in the vaccination room, requires the incorporation of a permanent strategy to update professionals' knowledge, that is, PE. This turnover of PHC professionals "demands a greater burden with the preparation and qualification of the professionals and, mainly, it compromises the continuity and the longitudinality of the assistance provided to the population". ${ }^{38: 32}$

The training of the professional who works in the vaccination room, as well as the time of experience with the work in immunization are aspects that can impact on patient safety. It should then be incorporated into the daily work of professionals who deal with the vaccination permanent updates, in order to minimize damages to the health of the user and increase the safety of the individual when he searches the vaccination room. ${ }^{39}$

PE has the potential to strengthen teamwork and positively impact the care provided to users. In addition, it has an essential potential for professional. However, for PE to achieve such achievements, it is necessary that it be developed continuously, as well as to have methodologies that allow the reflection of daily practice ${ }^{40}$ In this way, the importance of incorporating the EP to the work routine in the vaccination room is verified, because with its transformative potential of daily work, it allows the appropriate professionals to practice immunization, acquisition of skills, technical knowledge and, mainly, provides the professional with more security in the practices carried out.

\section{CONCLUSION AND IMPLICATIONS FOR PRACTICE}

Vaccine work requires the professional to have the technical skills and up-to-date knowledge to meet the immunization demands.

Frequent changes, adverse events, professional responsibility, the constant search for safety and the quality of the assistance provided in vaccination, as well as the daily obstacles of the work in the vaccination room reveal the need to incorporate PE into professionals. However, it is evident in this study that the educational activities developed for the vaccination professionals are not based on problems that are experienced on a daily basis and do not meet the PNEPS recommendations. The updates, when they occur, are for the transmission of information and not based on problematizing situations, which is not very effective.
Another aspect that deserves attention in this study is the need for knowledge about immunization to be multidisciplinary and not only for the nursing professionals who deal daily in the vaccination room. Thus, the findings of this study have implications for the practice of care and for teaching in Health and Nursing.

This study presents as a limitation the intentional sampling, when selecting the nursing professionals participating in a health region of Minas Gerais. However, based on the information collected, intentional sampling can be considered representative of similar populations and conditions in multiple-case studies with literal replication data saturation. ${ }^{18}$

Considering the relevance of $\mathrm{PE}$ in the vaccination room and of this subject in Public Health, it is necessary to carry out other researches in the other Brazilian regions and in other localities.

Finally, it is understood the need to incorporate the PE into vaccination rooms, since it presents potential transforming daily practices, a fundamental aspect to day-to-day work in the vaccination room against the knowledge that presents an accelerated process of transformation.

\section{FINANCIAL SUPPORT}

This study was financed Public Notice 14/2013. Research Program for SUS (PPSUS - Programa de Pesquisa para o SUS) process CBB-APQ-03509-13. It was approved and financed through the $\mathrm{PIBIC} / \mathrm{CNPq}$.

\section{REFERENCES}

1. Maffesoli M. Elogio da razão sensível. Tradução de Albert Christophe Migueis Stuckenbruck. 4ª ed. Petrópolis (RJ): Vozes; 2008.

2. Ministério da Saúde (BR). Secretaria de Vigilância em Saúde. Programa Nacional de Imunizações: aspectos históricos dos calendários de vacinação e avanços dos indicadores de coberturas vacinais, no período de 1980 a 2013. Boletim Epidemiológico [Internet]. 2015; [cited 2019 fev 02]; 46(30):1-13. Available from: http://portalarquivos2.saude. gov.br/images/pdf/2015/outubro/14/besvs-pni-v46-n30.pdf

3. Oliveira VC, Tavares LOM, Maforte NTP, Silva LNLR, Rennó HMS, Amaral GG, Viegas SMF. A percepção da equipe de enfermagem sobre a segurança do paciente em sala de vacinação. Rev Cuid [Internet]. 2018 jan/abr; [cited 2019 fev 02]; 10(1). Available from: https:// revistacuidarte.udes.edu.co/index.php/cuidarte/article/view/590 DOI: https://doi.org/10.15649/cuidarte.v10i1.590

4. Martins JRT, Alexandre BGP, Oliveira VC, Viegas SMF. Permanent education in the vaccination room: what is the reality?. Rev Bras Enferm [Internet]. 2018; [cited 2019 fev 02]; 71(Suppl 1):668-76. Available from: http://www.scielo.br/scielo.php?script=sci_arttext\&pid=S003471672018000700668\&Ing=en DOI: http://dx.doi.org/10.1590/00347167-2017-0560

5. Sena RR, Grillo MJCI, Pereira LA, Belga SMMF, França BD, Freitas CP. Educação permanente nos serviços de saúde: atividades educativas desenvolvidas no estado de Minas Gerais, Brasil. Rev Gaúcha Enferm [Internet]. 2017; [cited 2019 fev 02]; 38(2):e64031. Available from: http://www.scielo.br/scielo.php?script=sci_arttext\&pid=S198314472017000200407\&lng=en DOI: http://dx.doi.org/10.1590/19831447.2017.02.64031

6. Oliveira VC, Rennó HMS, Santos YR, Rabelo AFG, Gallardo MPS, Pinto IC. Educação para o trabalho em sala de vacina: percepção dos profissionais de enfermagem. R Enferm Cent O Min [Internet]. 2016 set/dez; [cited $2017 \mathrm{dez} 13$ ]; 6(3):2331-2341. Available from: http:// www.seer.ufsj.edu.br/index.php/recom/article/viewFile/1180/1166 DOI: http://dx.doi.org/10.19175/recom.v6i3.1180 
7. Domingues CMAS, Woycicki JR, Rezende KS, Henriques CMP. Programa nacional de imunização: a política de introdução de novas vacinas. Rev Eletr Gestão Saúde [Internet]. 2015; [cited 2017 nov 28]; 6(Supl 4):3250-3274. Available from: http://periodicos.unb.br/index.php/ rgs/article/view/3331

8. Ministério da Saúde (BR). Secretaria de Vigilância em Saúde. Departamento de Vigilância das Doenças Transmissíveis. Manual de Rede de Frio do Programa Nacional de Imunizações. 5 $5^{\text {a }}$ ed. Brasília (DF): Ministério da Saúde; 2017. p.136.

9. Ministério da Saúde (BR). Secretaria de Vigilância em Saúde. Departamento de Vigilância das Doenças Transmissíveis. Manual de Normas e Procedimentos para Vacinação. Brasília (DF): Ministério da Saúde; 2014. p.176.

10. Waldman EA, Sato APS. Trajetória das doenças infecciosas no Brasil nos últimos 50 anos: um contínuo desafio. Rev Saúde Pública [Internet]. 2016; [cited $2017 \mathrm{dez} 13$ ]; 50(68):1-18. Available from: http://www.scielo. br/pdf/rsp/v50/pt_0034-8910-rsp-S1518-87872016050000232.pdf DOI: http://dx.doi.org/10.1590/S1518-8787.2016050000232

11. Mothiba T, Tladi F. Challenges faced by professional nurses when implementing the Expanded Programme on Immunisation at rura clinics in Capricorn District, Limpopo. Afr J Prim Health Care Fam Med [Internet]. 2016 may; [cited $2017 \mathrm{dez}$ 10]; 8(2):e1-5. Available from: http://www.phcfm.org/index.php/phcfm/article/viewFile/923/pdfhttp:// dx.doi.org/10.4102/phcfm.v8i2.923

12. Ford KJ, Lang S, Pollard AJ, McCarthy ND. A quantitative review of healthcare professionals' questions to a local immunization advice service: 4299 enquiries from 3 years. Journal of Public Health [Internet]. $2015 \mathrm{sep}$; [cited $2017 \mathrm{dez}$ 10]; 38(3):578-584. Available from: DOI: https://doi.org/10.1093/pubmed/fdv112

13. Raglione D, Bezerra GAM, Lopes MH, Nerger MLBR, Guimarães TC, Sartori AMC. Avaliação da rede de frio para conservação de vacinas em unidades básicas de saúde das regiões Sul e Centro-Oeste do município de São Paulo em 2011-2012. Epidemiol Serv Saúde [Internet]. 2016 jan/ mar; [cited 2017 out 21]; 25(1):65-74. Available from: http://www.scielo. br/pdf/ress/v25n1/2237-9622-ress-25-01-00065.pdf DOl: http://dx.doi. org/10.5123/s1679-49742016000100007

14. Assad SGB, Corvino MPF, Santos SCP, Cortez EA, Souza FL. Educação permanente em saúde e atividades de vacinação: revisão integrativa. Rev Enferm UFPE [Internet]. 2017; [cited 2017 out 26]; 11(1):410-21. Available from: http://www.revista.ufpe.br/revistaenfermagem/index. php/revista/article/view/10108/pdf_2425 10.5205/reuol.7995-699314-SM.1101sup201721

15. Oliveira VC, Gallardo MDPS, Arcêncio RA, Gontijo TL, Pinto IC. Avaliação da qualidade de conservação de vacinas na Atenção Primária à Saúde. Ciênc Saúde Coletiva [Internet]. 2014 set; [cited 2017 nov 25]; 19(9):3889-3898. Available from: http://www.scielo. br/pdf/csc/v19n9/1413-8123-csc-19-09-3889.pdf DOI: http://dx.doi. org/10.1590/1413-81232014199.12252013

16. Falkenberg MB, Mendes TPL, Moraes EP, Souza EM. Educação em saúde e educação na saúde: conceitos e implicações para a saúde coletiva. Ciênc Saúde Coletiva [Internet]. 2014 mar; [cited 2017 out 17]; 19(3):847-852. Available from: http://www.scielo.br/pdf/csc/v19n3/14138123-csc-19-03-00847.pdf DOI: http://dx.doi.org/10.1590/141381232014193.01572013

17. Pereira AM, Ivo OP. Causas do atraso do calendário vacinal em menores de dois anos. Revista Enfermagem Contemporânea [Internet]. 2016 nov; [cited $2017 \mathrm{dez}$ 10]; 5(2):210-218. Available from: https://www5. bahiana.edu.br/index.php/enfermagem/article/view/1068 DOI: http:// dx.doi.org/10.17267/2317-3378rec.v5i2.1068

18. Fossa AM, Protti AM, Rocha MCP, Horibe TM, Pedroso GER Conservação e administração de vacinas: a atuação da enfermagem. Saúde Rev [Internet]. 2015 abr/ago; [cited 2017 dez 10]; 15(40):85-96. Available from: https://www.metodista.br/revistas/revistas-unimep/ index.php/sr/article/view/2538http://dx.doi.org/10.15600/2238-1244/ sr.v15n40p85-96
19. Feitosa LR, Feitosa JÁ, Coriolano MWL. Conhecimentos e práticas do auxiliar de enfermagem em sala de imunização. Cogitare Enferm [Internet]. 2010 out/dez; [cited 2018 jan 10]; 15(4):695-701. Available from: https://revistas.ufpr.br/cogitare/article/view/20370 DOI: http:// dx.doi.org/10.5380/ce.v15i4.20370

20. Ministério da Saúde (BR). Secretaria de Gestão do Trabalho e da Educação na Saúde. Manual Técnico 2018. Programa para o Fortalecimento das Práticas de Educação Permanente em Saúde no SUS - PRO EPSSUS. Diário Oficial da União [Internet]. Brasília (DF): Ministério da Saúde; 2018. p.39; [cited 2019 fev 02]. Available from: http://portalarquivos2. saude.gov.br/images/pdf/2018/marco/28/Manual-Tecnico-PRO-EPSSUS-MINUTA17-10.pdf

21. Ministério da Saúde (BR). Secretaria-Executiva. Subsecretaria de Assuntos Administrativos. Educação Permanente. $1^{\text {a }}$ ed. $1^{\text {a }}$ reimpr Brasília (DF): Ministério da Saúde; 2014. p.120; [cited 2019 fev 02] Available from: http://bvsms.saude.gov.br/bvs/publicacoes/educacao_ permanente_saude_movimento_instituinte.pdf

22. Campos KFC, Sena RR, Silva KL. Educação permanente nos serviços de saúde. Esc Anna Nery [Internet]. 2017; [cited 2019 fev 02]; 21(4):e20160317. Available from: http://www.scielo.br/scielo. php?script=sci_arttext\&pid=S1414-81452017000400801\&lng=en DOI: http://dx.doi.org/10.1590/2177-9465-ean-2016-0317

23. Merhy EE. Educação permanente em movimento: uma política de reconhecimento e cooperação, ativando os encontros do cotidiano no mundo do trabalho em saúde, questões para os gestores, trabalhadores e quem mais quiser se ver nisso. Saúde em Redes [Internet]. 2015 [cited 2017 nov 03]; 1(1):7-14. Available from: http://revista.redeunida. org.br/ojs/index.php/rede-unida/article/view/309/15 DOI: http://dx.doi. org/10.18310\%2F2446-4813.2015v1n1p07-14

24. Ternopolski CA, Baratieri T. Lenstck MH. Eventos adversos pós-vacinação: educação permanente para a equipe de enfermagem. Rev Espaço para a Saúde [Internet].2015 out/dez; [cited 2017 set 13]; 16(4):109-119. Available from: http://espacoparasaude.fpp.edu.br/index.php/espacosaude/article/view/388 DOI: 10.22421/1517-7130.2015v16n4p109

25. Yin RK. Estudo de Caso: Planejamento e métodos. Tradução de Cristhian Matheus Herrera. $5^{\underline{a}}$ ed. Porto Alegre: Bookman; 2015.

26. Maffesoli M. O conhecimento comum: introdução à sociologia compreensiva. Tradução de Aluizio Ramos Trinta. Porto Alegre: Sulina; 2010.

27. Bardin L. Análise de conteúdo. Tradução de L. A. Reto, A. Pinheiro. Lisboa: Edições 70; 2011.

28. Santos CAPS, Costa RS, Silva JLM, Santos MRF, Gomes BLF Conhecimento, atitude e prática dos vacinadores sobre vacinação infantil em Teresina-PI, 2015. Epidemiol Serv Saúde [Internet]. 2017 mar; [cited 2017 nov 02]; 26(1):133-140. Available from: http://www. scielosp.org/pdf/ress/v26n1/2237-9622-ress-26-01-00133.pdf DOI: http://dx.doi.org/10.5123/s1679-49742017000100014

29. Cunha AZS, Rezende MS, Weigelt LD, Krug SBF, Feil Al. Implicações da educação permanente no processo de trabalho em saúde. Rev Espaço Saúde [Internet]. 2014; [cited 2017 nov 02]; 15(4):64-75. Available from http://online.unisc.br/acadnet/anais/index.php/semic/article/view/12250 DOI: 10.1590/2177-9465-EAN-2017-0060

30. Wegner W, Silva SC, Kantorski KJC, Predebon CM, Sanches MO, Pedro ENR. Educação para cultura da segurança do paciente: Implicações para a formação profissional. Esc Anna Nery [Internet]. 2016 jul/set; [cited 2017 nov 06]; 20(3):1-9. Available from: http://www.redalyc.org/ pdf/1277/127745807012.pdf DOI: http://dx.doi.org/10.5935/14148145.20160068

31. Masika CW, Atieli H, Were T. Knowledge, Perceptions, and Practice of Nurses on Surveillance of Adverse Events following Childhood Immunization in Nairobi, Kenya. BioMed Research International [Internet] 2016; [cited 2017 nov 04]. Available from: https://www.ncbi.nlm.nih.gov/ pubmed/28078288 DOI: http://dx.doi.org/10.1155/2016/3745298

32. Maffesoli M. Elogio da razão sensível. Tradução de Albert Christophe Migueis Stuckenbruck. Petrópolis (RJ): Vozes; 1998. 
33. Fernandes FC, Cortez EA, Laprovita D, Almeida LP, Ferreira AF, Corvino MPF. Educação permanente em saúde sob a perspectiva de Agostinho de Hipona. Rev Bras Enferm [Internet]. 2017 jun; [cited 2017 out 26]; 70(3):656-61. Available from: http://www.scielo.br/pdf/ reben/v70n3/0034-7167-reben-70-03-0656.pdf DOI: http://dx.doi. org/10.1590/0034-7167-2016-0484

34. Brito MFP, Gerin L, Couto ECA, Cunha IS, Corsini MCMM, Gonçalves MC. Caracterização das notificações de procedimentos inadequados na administração de imunobiológicos em Ribeirão Preto, São Paulo, 2007-2012. Epidemiol Serv Saúde [Internet]. 2014; [cited 2017 out 26]; 23(1):33-44. Available from: http://scielo.iec.pa.gov.br/scielo. php?script=sci_arttext\&pid=S167949742014000100004\&lng=pt\&nr m=iso DOI: http://dx.doi.org/10.5123/S1679-49742014000100004

35. Kim M, Lee YK, Kim TE, Kong I, YangH, Suh ES. Surveillance and compensation claims for adverse events following immunization from 2011 to 2016 in the Republic of Korea. Clin Exp Vaccine Res [Internet]. 2017 jul; [cited 2017 nov 04]; 6(2):146-155. Available from: https:// synapse.koreamed.org/Synapse/Data/PDFData/0209CEVR/cevr-6146.pdf DOI: http://dx.doi.org/10.7774/cevr.2017.6.2.146

36. Manca T. "One of the greatest medical success stories:" Physicians and nurses' small stories about vaccine knowledge and anxieties. Social Science \& Medicine [Internet]. 2018 jan; [cited 2017 nov 04]; 196:182-189. Available from: DOI: http://dx.doi.org/10.1016/j. socscimed.2017.11.027
37. Araújo TME, Almeida PD, Bezerra FKO. Conhecimento de agentes comunitários de saúde sobre vacinação da criança no $1^{\circ}$ ano de vida. Rev Enferm UFPE [Internet]. 2015; [cited 2017 nov 02]; 9(8):8778-7. Available from: http://www.scielo.br/pdf/reben/v65n1/18.pdf

38. Gonçalves CR, Cruz MT, Oliveira MP, Morais AJD, Moreira KS, Rodrigues $\mathrm{CAQ}$, et al. Recursos humanos: fator crítico para as redes de atenção à saúde. Saúde Debate [Internet]. 2014 mar; [cited 2017 nov 02]; 38(100):26-34. Available from: http://www.scielo.br/pdf/ sdeb/v38n100/0103-1104-sdeb-38-100-0026.pdf DOI: http://dx.doi. org/10.5935/0103-104.20140012

39. Tertuliano GC, Maszlock VP. Segurança do paciente e sala de vacinas. Revista Cuidado em Enfermagem-CESUCA [Internet]. 2016 jan; [cited 2017 nov 02];2(2):33-43. Available from: http://ojs.cesuca.edu.br/index. $\mathrm{php} /$ revistaenfermagem/article/view/1031

40. Puggina CC, Amestoy SC, Fernandes HN, Carvalho LA, Báo ACP Alves FO. Educação permanente em saúde: instrumento de transformação do trabalho de enfermeiros. Espaç Saúde [Internet]. 2015 out/dez; [cited 2017 nov 01]; 16(4):87-97. Available from: http:// pesquisa.bvsalud.org/portal/resource/pt/biblio-834523 DOI: http:// dx.doi.org/10.22421/1517-7130.2015v16n4p87 